\title{
Topographical regulation of primary cilia orientation and length in mesenchymal stem cells
}

\author{
R McMurray*, MM Knight \\ From First International Cilia in Development and Disease Scientific Conference (2012) \\ London, UK. 16-18 May 2012
}

\section{Introduction}

The role of the primary cilia in directing the differentiation of mesenchymal stem cells (MSCs) has recently been demonstrated in response to chemical cues. In addition there is increasing evidence for the role of the primary cilia in sensing environmental cues. The purpose of this study was to test the hypothesis that surface topography, which regulates MSC differentiation, influences primary cilia structure and function.

\section{Methods}

Grooved topographical surfaces were produced by hot embossing a quartz stamp into the polymer polycaprolactone $(\mathrm{PCL})$ and then coating in fibronectin $(10 \mathrm{ug} / \mathrm{ml})$ to promote even cell attachment. MSCs were cultured for 1 and 3 days in basal media $(\alpha-$ MEM $+10 \%$ FBS) followed by 24 hours culture in serum free media on either grooved (540nm deep) or planar surfaces. Cells were fixed and stained with acetylated $\alpha$-tubulin to label the primary cilia which were visualised using confocal microscopy.

\section{Results}

MSCs and their primary cilia were observed to orientate parallel to the grooves. In addition primary cilia length was found to be significantly different $(\mathrm{p}<0.005)$ between the two surfaces with mean lengths $3.1 \mu \mathrm{m}$ and $2.6 \mu \mathrm{m}$ for cells on grooved and planar surfaces respectively.

\section{Discussion}

The mechanism for cilia alignment in response to topography is unclear but is unlikely to be mediated by alignment of the extracellular matrix as suggested in tissue. These changes in primary cilia structure may be involved in mediating stem cell differentiation and other changes in cell function associated with the topographical cues.

\footnotetext{
* Correspondence: r.mcmurray@qmul.ac.uk
}

Queen Mary, University of London, UK

(c) 2012 McMurray and Knight; licensee BioMed Central Ltd. This is an Open Access article distributed under the terms of the Creative Commons Attribution License (http://creativecommons.org/licenses/by/2.0), which permits unrestricted use, distribution, and reproduction in any medium, provided the original work is properly cited.
Acknowledgements

We thank Carol-Anne Smith for providing the surfaces.

Published: 16 November 2012

doi:10.1186/2046-2530-1-S1-P34

Cite this article as: McMurray and Knight: Topographical regulation of primary cilia orientation and length in mesenchymal stem cells. Cilia 2012 1(Suppl 1):P34.
Submit your next manuscript to BioMed Central and take full advantage of:

- Convenient online submission

- Thorough peer review

- No space constraints or color figure charges

- Immediate publication on acceptance

- Inclusion in PubMed, CAS, Scopus and Google Scholar

- Research which is freely available for redistribution 